\title{
Tocolytic effect of combined sildenafil citrate and nifedepine versus nifedipine alone for management of preterm labour at a tertiary centre
}

\author{
Urmila Karya, Anupam Rani, Anshi Srivastava*
}

Department of Obstetrics and Gynecology, L.L.R.M. Medical College, Meerut, Uttar Pradesh, India

Received: 07 February 2021

Accepted: 09 March 2021

*Correspondence:

Dr. Anshi Srivastava,

E-mail: srivastava.anshi40@gmail.com

Copyright: ( ) the author(s), publisher and licensee Medip Academy. This is an open-access article distributed under the terms of the Creative Commons Attribution Non-Commercial License, which permits unrestricted non-commercial use, distribution, and reproduction in any medium, provided the original work is properly cited.

\begin{abstract}
Background: This study was conducted to evaluate tocolytic effect of sildenafil citrate and nifedipine versus nifedipine alone for management of preterm labour.

Methods: Prospective randomized study on 80 women aged 18-35 years with singleton pregnancy of 28-34 weeks gestation with preterm labour, fulfilling the inclusion criteria were randomly divided in two groups of 40 each. In regimen A women were given sildenafil citrate and nifedipine while in regimen B nifedipine alone for 72 hours as tocolysis.

Results: Higher mean latency in sildenafil and nifedipine combination regimen compared to nifedipine alone regimen $(28.23 \pm 18.3$ versus $12.98 \pm 13.35$ days, $\mathrm{p}<0.001)$. In regimen $\mathrm{A}$, less days of hospital stay $(3.23 \pm 0.92$ versus $3.9 \pm 0.38$ days, $\mathrm{p}<0.0001$ ); improve perinatal outcomes in form of fewer deliveries during hospitalization or within 7 days after discharge $(\mathrm{p}=0.018)$; reduction in NICU admission $(0.68 \pm 1.54$ versus $3.18 \pm 4.61$ days, $\mathrm{p}=0.002)$; improvement in birth weight $(\mathrm{p}<0.001)$ and fewer neonatal complications. Only minor side-effects like facial flushing $(42.5 \%$ versus $22.5 \%, \mathrm{p}=0.029)$, headache ( $40 \%$ versus $25 \%$ ), dyspepsia ( $15 \%$ versus $2.5 \%, \mathrm{p}=0.047)$, nasal congestion, palpitation, hypotension, constipation, nausea, dizziness were seen.

Conclusions: Our study found combination of sildenafil citrate with nifedipine as superior and successful regimen with future potential as a tocolytic therapy.
\end{abstract}

Keywords: Preterm labour, Tocolytic agents

\section{INTRODUCTION}

Preterm labour is defined as the onset of regular painful uterine contractions with effacement and dilatation of the cervix prior to the completion of 37 weeks (259 days) of gestation counting from the first day of the last menstrual period and after the attainment of period of viability. It is the leading cause of neonatal morbidity and mortality worldwide and accounts for $75 \%$ of neonatal deaths and $50 \%$ of long term morbidity, including respiratory disease and neurodevelopmental impairment. ${ }^{1}$

Major goal of the obstetrician in this regard is to postpone delivery for 24-48 hours to allow enough time for administration of corticosteroids to reduce the incidence and severity of neonatal complication
Nifedipine, a calcium channel blocker is a prototype of dihydropyridine with a rapid onset and short duration of action. It act by inhibiting voltage dependent $\mathrm{L}$ type calcium channel, thus decreases the calcium influx into the cells, leads to smooth muscle relaxation and negative inotropic and chronotropic effects on the heart. Vasodilation, followed by a baroreceptor-mediated increase in sympathetic tone then results in indirect cardio-stimulation. It is marketed as an anti-hypertensive agent. The oral administration route, the availability of immediate and slow-release preparations, the low incidence of side effects (mild), and its limited costs explain the attraction to this medication from the obstetric field and its rapid and widespread distribution.

In one meta-analysis, nifedipine was found to be more effective and safer than ritodrine and other traditional 
tocolytics agents while another meta-analysis recommended it as drug of choice for threatened preterm labour. ${ }^{2,3}$

Sildenafil, the citrate salt of 1-(4-ethoxy-3-(6,7-dihydro1-methyl-7-oxo-3-propyl-1H-pyrazolo(4,3-d)

pyrimidine- 5- phenyl-sulphonyl) -4-methylpiperazine prevent the degradation of second messenger cyclic guanosine 3',5'-monophosphate by the enzyme PDE-5 which increased nitric oxide production and consequent vascular smooth muscle relaxation and vasodilation. ${ }^{6}$ The relaxant action of cGMP in smooth muscle, through its downstream effector the enzyme protein kinase $G$, results in reduced intracellular calcium levels and a reduced sensitivity of the contractile elements to calcium. The vasodilator effect of sildenafil citrate also manifested on uterine and myometrial vessels result in increased uterine flow and endometrial thickening, putatively promoting an increase in fetal weight. ${ }^{2,4,5}$

To date, very few studies have explored the tocolytic effect of sildenafil and the use of sildenafil citrate in human pregnancy has been confirmed to relatively small RCTs and reports. Further availability of slow and sustained release preparations, low incidence of side effects, limited cost and ease of administration as compared to other tocolytics, attracted our attention to use the medication for preterm labour. Hence, present study was an endeavour to evaluate whether the synergistic tocolytic effect of combined sildenafil citrate and nifedipine regimen are superior to nifedipine alone or not.

\section{METHODS}

The prospective randomized single blinded study was conducted in department of obstetrics and gynecology, L.L.R.M. Medical college and associated with SVBP Hospital from October 2019 to September 2020 comprising 80 women aged 18-35 years with singleton pregnancy of 28-34 weeks gestation; fulfilling the inclusion criteria attending outpatient clinics and emergency. An informed consent was obtained from each woman. Ethical clearance was taken from the institutional ethical committee.

\section{Inclusion criteria}

Preterm labour with contraction frequency $(\geq 4$ contraction every 20 minutes or $>8$ contraction in 1 hour), accompanied by one of the following: cervical dilationbetween 0 and $3 \mathrm{~cm}$ in nulliparous, between 1 and $3 \mathrm{~cm}$ for multiparous; cervical effacement $>50 \%$. With intact membrane

\section{Exclusion criteria}

Pregnant woman $<28$ week or $>34$ week of gestation. Advanced cervical dilation $>3 \mathrm{~cm}$ with or without bulging membrane into the vagina. Ruptured fetal membranes (PPROM). Suspected chorioamniotis.
Overdistended uterus- polyhydramnios, multiple pregnancy. Medically indicated preterm delivery like eclampsia, severe pre-eclampsia. Placental abruption, antepartum hemorrhage, severe anemia, fever above $38^{\circ} \mathrm{C}$. Chronic hypertension, cardiac disease, diabetes mellitus, chronic renal disease, bronchial asthma, hypotension $(<90 / 50 \mathrm{mmHg})$. Congenital anomalies in fetus, IUGR $<5^{\text {th }}$ percentile. Congenital uterine anomalies. Nonreassuring fetal heart rate tracing. Contraindication to nifedipine and sildenafil.

Gestational age was confirmed either by a documented first trimester USG or a reliable menstrual date, with USG performed before 20 weeks of gestation and detailed history taken. General, systemic and obstetric examination was done. All routine antenatal investigations along with C-reactive protein were sent. High vaginal swab culture and sensitivity was done. Cervical length was also measured by using TVS. Participants were randomized using sealed numbered opaque envelopes.

Regimen A (sildenafil citrate and nifedipine combined regimen)- women were given sildenafil citrate $25 \mathrm{mg}$, vaginally 8 -hourly along with nifedipine $20 \mathrm{mg}$ stat orally followed by $10 \mathrm{mg}$ every 6 hourly.

Regimen B (Nifedipine alone regimen)- $20 \mathrm{mg}$ orally followed by $10 \mathrm{mg}$ orally every 6 hourly.

Both regimens were given for 72 hours. Uterine contractions was monitored clinically and by an external tocodynamometer. Tocolytic drugs were discontinued in the face of progression to a cervical dilation of $4 \mathrm{~cm}$ or more, rupture of membranes, no decrease in contraction after 12 hours or if there was a suspicion of chorioamnionitis. Both groups were given prophylactic steroid coverage and undelivered women were discharged on progesterone (vaginally) 200 microgram/ 12 hourly till 34 weeks. Prophylactic antibiotics was given for high vaginal culture positive women. All recruited women was followed till delivery and maternal and fetal outcomes were noted. Neonates were followed at 1 month of age for assessment of early neurodevelopmental morbidity.

\section{RESULTS}

Data were compiled and majority of women in the study were in the age group 18-23 years with mean age of $27.75 \pm 6.1$ years in sildenafil citrate + nifedipine regimen and 27.6 \pm 6.7 years in nifedipine alone regimen. Most of the women were illiterate in both regimens $(47.5 \%$ in regimen $\mathrm{A}$ and $40 \%$ in regimen B). Majority of women were either overweight ( $35 \%$ and $42.5 \%$ ) or had low BMI (40\% and $35 \%$ ) in both regimens. Most women belonged to either lower $37.5 \%$ in regimen $\mathrm{A}$ and $35 \%$ in regimen B) or upper lower (45\% in regimen $\mathrm{A}$ and $50 \%$ in regimen $\mathrm{B}$ ) socioeconomic status according to modified Kuppuswamy scale. Majority of women presented with preterm labour in both regimens were multiparous $62.5 \%$ and $65 \%$ respectively. 
Table 1: Distribution of obstetric variable.

\begin{tabular}{|c|c|c|c|}
\hline $\begin{array}{l}\text { Obstetric } \\
\text { variable }\end{array}$ & Variables & $\begin{array}{l}\text { Regimen A nifedipine + } \\
\text { sildenafil citrate }(n=40)\end{array}$ & Regimen B nifedipine ( $n=40)$ \\
\hline \multirow{2}{*}{ Gravida } & Primigravida & $15(37.5 \%)$ & $14(35.0 \%)$ \\
\hline & Multigravida & $25(62.5 \%)$ & $26(65 \%)$ \\
\hline \multirow{3}{*}{$\begin{array}{l}\text { Gestational age } \\
\text { (weeks) }\end{array}$} & 28 to $<32$ & $18(45.0 \%)$ & $16(40.0 \%)$ \\
\hline & 32 to 34 & $22(55.0 \%)$ & $24(60.0 \%)$ \\
\hline & Mean \pm SD & $32.1 \pm 4.4$ & $32.2 \pm 4.2$ \\
\hline \multirow{2}{*}{$\begin{array}{l}\text { Cervical length } \\
\text { (cm) }\end{array}$} & $<2.5$ & $26(65.0 \%)$ & $21(52.5 \%)$ \\
\hline & $\geq 2.5$ & $14(35.0 \%)$ & $19(47.5 \%)$ \\
\hline \multirow{2}{*}{$\begin{array}{l}\text { C-reactive } \\
\text { protein }\end{array}$} & $0-4 \mathrm{mg} / \mathrm{dl}$ & $27(67.5 \%)$ & $32(80.0 \%)$ \\
\hline & $>4 \mathrm{mg} / \mathrm{dl}$ & $13(32.5 \%)$ & $8(20.0 \%)$ \\
\hline \multirow{2}{*}{$\begin{array}{l}\text { High vaginal } \\
\text { swab culture }\end{array}$} & Culture -ve & $33(82.5 \%)$ & $36(90 \%)$ \\
\hline & Culture +ve & $7(17.5 \%)$ & $4(10 \%)$ \\
\hline \multirow{2}{*}{$\begin{array}{l}\text { Tocolytic } \\
\text { therapy }\end{array}$} & $\begin{array}{l}\text { Mean dose of sildenafil citrate } \\
\text { given }(\mathrm{mg})(\text { Mean } \pm \text { SD })\end{array}$ & $205.6 \pm 46.87$ & -------- \\
\hline & $\begin{array}{l}\text { Mean dose of nifedipine given } \\
(\mathrm{mg})(\text { Mean } \pm \text { SD })\end{array}$ & $134.50 \pm 16.94$ & $131.0 \pm 23.07$ \\
\hline
\end{tabular}

Table 2: Primary outcome according to treatment.

\begin{tabular}{|c|c|c|c|}
\hline Variables & $\begin{array}{l}\text { Regimen A nifedipine + } \\
\text { sildenafil citrate }\end{array}$ & $\begin{array}{l}\text { Regimen B } \\
\text { nifedipine }\end{array}$ & P value ${ }^{*}$ \\
\hline Delivery within 24 hours n (\%) & $1(2.5 \%)$ & $3(7.5 \%)$ & $0.305^{*}$ \\
\hline Delivery within 48 hours n (\%) & $2(5.0 \%)$ & $4(10.0 \%)$ & $0.396^{*}$ \\
\hline Delivery within 72 hours $n(\%)$ & $5(12.5 \%)$ & $14(35.0 \%)$ & $0.018^{*}$ \\
\hline Cases remained undelivered during hospitalization n (\%) & $32(80.0 \%)$ & $19(47.5 \%)$ & $0.002^{*}$ \\
\hline Delivery after discharge in $\leq 7$ days from admission $\mathbf{n}(\%)$ & $2(5.0 \%)$ & $3(7.5 \%)$ & $0.644^{*}$ \\
\hline Total days of hospital stay (mean \pm SD) & $3.23 \pm 0.92$ & $3.9 \pm 0.38$ & $<0.001^{\#}$ \\
\hline $\begin{array}{l}\text { Latency (time in days from randomisation till delivery } \\
(\text { Mean } \pm \text { SD) }\end{array}$ & $28.23 \pm 18.3$ & $12.98 \pm 13.35$ & $<0.001^{\#}$ \\
\hline
\end{tabular}

*Chi square test, " Independent student t test

Table 3: Side effects of drugs.

\begin{tabular}{|lllll|}
\hline Side- effects & $\begin{array}{l}\text { Regimen A nifedipine }+ \\
\text { sildenafil citrate }(\mathbf{n}=\mathbf{4 0})\end{array}$ & $\begin{array}{l}\text { Regimen B nifedipine } \\
(\mathbf{n = 4 0 )}\end{array}$ & $\begin{array}{l}\text { Total } \\
(\mathbf{n = 8 0})\end{array}$ & \begin{tabular}{l} 
P value* \\
\hline Facial flushing
\end{tabular} \\
\hline Headache & $17(42.5 \%)$ & $8(22.5 \%)$ & 25 & 0.029 \\
\hline Dyspepsia & $16(40.0 \%)$ & $10(25 \%)$ & 26 & 0.644 \\
\hline Nasal congestion & $6(15 \%)$ & $1(2.5 \%)$ & 7 & 0.047 \\
\hline Palpitation & $4(10 \%)$ & $1(2.5 \%)$ & 5 & 0.165 \\
\hline Constipation & $3(7.5 \%)$ & $4(10.0 \%)$ & 7 & 0.692 \\
\hline Hypotension & $1(2.5 \%)$ & $4(10.0 \%)$ & 5 & 0.165 \\
\hline Nausea & $2(5 \%)$ & $1(2.5 \%)$ & 3 & 0.556 \\
\hline Dizziness & $2(5.0 \%)$ & $3(7.5 \%)$ & 5 & 0.644 \\
\hline Body myalgia & $2(5.0 \%)$ & $2(5.0 \%)$ & 4 & 1.000 \\
\hline Abnormal vision & $1(2.5 \%)$ & $0(0.0 \%)$ & 1 & 1.000 \\
\hline *Chi square test & $0(0 \%)$ & $0(0 \%)$ & 0 & - \\
\hline
\end{tabular}

*Chi square test

Various risk factors of preterm birth were found in both study groups like history of preterm birth $(17.5 \%$ versus $15 \%), \mathrm{D}$ and $\mathrm{C}(2.5 \%)$, spontaneous abortion $(2.5 \%$ versus $7.5 \%$ ). Poor nutrition status were seen in both regimens (42.5\% and $37.5 \%$ respectively). Prolonged working hours were present in $12.5 \%$ women in regimen A and $7.5 \%$ in regimen B. Substance abuse like smoking, tobacco chewing were also present in few women with preterm labour (5\% and $2.5 \%$ ) (Figure 1). 
Table 4: Perinatal outcomes.

\begin{tabular}{|c|c|c|c|c|}
\hline $\begin{array}{l}\text { Perinatal } \\
\text { outcomes }\end{array}$ & Variables & $\begin{array}{l}\text { Regimen A nifedipine + } \\
\text { sildenafil citrate }(n=40)\end{array}$ & $\begin{array}{l}\text { Regimen B } \\
\text { nifedipine (n=40) }\end{array}$ & P value* \\
\hline \multirow{4}{*}{$\begin{array}{l}\text { Gestational age } \\
\text { at delivery }\end{array}$} & Very preterm $(28-<32$ weeks $)$ & $3(7.5 \%)$ & $5(12.5 \%)$ & \multirow{4}{*}{$<0.001$} \\
\hline & Moderate preterm $(32-<34$ weeks) & $5(12.5 \%)$ & $20(50.0 \%)$ & \\
\hline & Late preterm $(34-<37$ weeks) & $18(45.0 \%)$ & $13(32.5 \%)$ & \\
\hline & Term ( $\geq 37$ weeks) & $14(35.0 \%)$ & $2(5.0 \%)$ & \\
\hline \multirow{2}{*}{$\begin{array}{l}\text { Birth weight } \\
\text { (grams) }\end{array}$} & $<2500 \mathrm{gm}(\mathrm{LBW})$ & $17(42.5 \%)$ & $35(87.5 \%)$ & \multirow{2}{*}{$<0.001$} \\
\hline & $\geq 2500 \mathrm{gm}$ & $23(57.5 \%)$ & $5(12.5 \%)$ & \\
\hline \multirow{2}{*}{$\begin{array}{l}\text { Apgar score } \\
\text { at } 5 \text { minute }\end{array}$} & $<7$ & $8(20.0 \%)$ & $19(47.5 \%)$ & \multirow{2}{*}{0.009} \\
\hline & $\geq 7$ & $32(80.0 \%)$ & $21(52.5 \%)$ & \\
\hline \multirow{2}{*}{ NICU admission } & No & $31(77.5 \%)$ & $21(52.5 \%)$ & \multirow{2}{*}{$0.001 *$} \\
\hline & Yes & $9(22.5 \%)$ & $28(35 \%)$ & \\
\hline $\begin{array}{l}\text { Total NICU stay } \\
\text { (days) }\end{array}$ & $($ Mean \pm SD $)$ & $0.68 \pm 1.54$ & $3.18 \pm 4.61$ & $0.002^{\#}$ \\
\hline \multirow{7}{*}{$\begin{array}{l}\text { Neonatal } \\
\text { complications }\end{array}$} & Respiratory distress & $4(10 \%)$ & $9(22.5 \%)$ & \\
\hline & G1 disturbances & $3(7.5 \%)$ & $8(20 \%)$ & \\
\hline & Intraventricular haemorrhage & $2(5 \%)$ & $5(12.5 \%)$ & \\
\hline & Neonatal jaundice & $7(17.5 \%)$ & $13(32.5 \%)$ & \\
\hline & Neonatal sepsis & $4(10 \%)$ & $10(25.0 \%)$ & \\
\hline & Perinatal death & $2(5 \%)$ & $5(12.5 \%)$ & \\
\hline & $\begin{array}{l}\text { Early neurodevelopment morbidity } \\
\text { within } 1 \text { month of delivery }\end{array}$ & $4(10 \%)$ & $6(15.0 \%)$ & \\
\hline
\end{tabular}

*Chi Square test, \#Independent student $t$ test

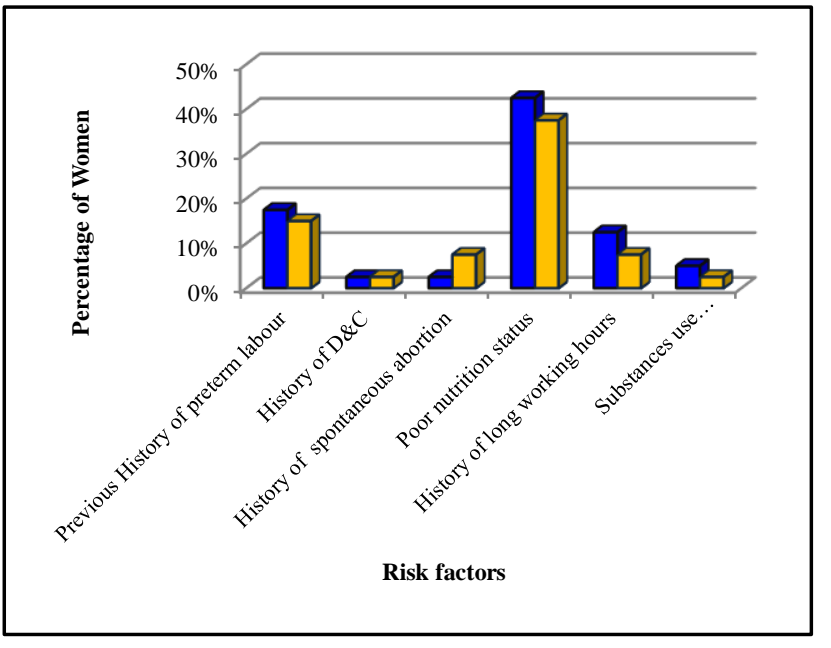

Figure 1: Risk factors.

Mean gestational age at the time of randomization was $32.1 \pm 4.4$ weeks in regimen $\mathrm{A}$ and $32.2 \pm 4.2$ weeks in regimen B. Cervical length was an important parameter of preterm birth prediction, measured at the time of enrollment in women with preterm labour. Cervical length $<2.5 \mathrm{~cm}$ were present in $65 \%$ women of regimen $\mathrm{A}$ and $52.5 \%$ women of regimen B. High level of Creactive protein was also seen in women with preterm labour pains i.e. $32.5 \%$ in regimen $\mathrm{A}$ and $20 \%$ in regimen $\mathrm{B}$ respectively. Positive high vaginal swab culture was found in $17.5 \%$ women in regimen $\mathrm{A}$ and $10 \%$ women in regimen $\mathrm{B}$, for which prophylactic antibiotics were given.
Sildenafil citrate as tocolytic was given for 72 hours in regimen A with mean dose of $205 \pm 46.87 \mathrm{mg}$. Mean dose of nifedipine in regimen A and B was $134 \pm 16.94$ and $131.0 \pm 23.07 \mathrm{mg}$ respectively. Higher mean latency (time in days from randomization till delivery) was observed in combined sildenafil citrate and nifedipine regimen, compared to nifedipine alone $(28.23 \pm 18.3$ versus $12.98 \pm 13.35$ days), which was statistically significant $(\mathrm{p}<0.001)$. Eighty percent women in regimen $\mathrm{A}$ and $47.5 \%$ women in regimen $\mathrm{B}$ remains undelivered during hospitalization which was also statistically significant $(\mathrm{p}=0.002)$. Only $12.5 \%$ women in regimen A were delivered within 72 hours of admission compared to $35 \%$ women in regimen $B(p=0.018)$. Total days of hospital stay was $3.23 \pm 0.92$ days in regimen $A$ and $3.9 \pm 0.38$ days in nifedipine alone regimen $(\mathrm{p}<0.0001)$.

Regarding gestational age at the time of deliveries, most of the deliveries in nifedipine + sildenafil citrate combination regimen A were either late preterm (45\%) or term $(35 \%)$ gestational age while in nifedipine alone regimen were moderate preterm $(50 \%)$. This association was found to be statistically significant $(\mathrm{p}<0.0002)$. Birth weight was significantly higher in regimen A compared to regimen $\mathrm{B}(57.5 \%$ versus $12.5 \%, \mathrm{p}<0.001)$. Newborn with birth weight $<2.5 \mathrm{~kg}$ were less in regimen $\mathrm{A}$ compared to regimen B $(42.5 \%$ versus $87.5 \%$, p value $<0.001$ ). Higher numbers of newborn had Apgar score $\geq 7$ in combination regimen, in comparison to nifedipine alone group (80\% versus $52.5 \%$ ). NICU admission was significantly lower in regimen A $(22 \%)$ compared to 
regimen $\mathrm{B}(47.5 \%)$. Total days of NICU stay was also significantly reduced in regimens $\mathrm{A}$ as compared to regimen $\mathrm{B}(0.68 \pm 1.54$ versus $3.18 \pm 4.61$ days; $\mathrm{p}=0.002)$. Early neurodevelopmental morbidity within 1 month was found in 4 babies (regimen A) and 6 babies (regimen B). Only minor side-effects like facial flushing $(42.5 \%$ versus $22.5 \%$; $\mathrm{p}=0.029)$, headache $(40 \%$ versus $25 \%)$, dyspepsia ( $15 \%$ versus $2.5 \% ; \mathrm{p}=0.047)$, nasal congestion $(10 \%$ versus $2.5 \%$ ) were seen in both regimens.

\section{DISCUSSION}

Despite considerable advances in our knowledge of myometrial physiology, our current understanding of mechanisms responsible for preterm labour and delivery remains limited. Nifedipine has been reported as an effective treatment for preterm labour in different studies. Sildenafil citrate causes myometrial relaxation in concentration dependent manner. The optimal dose of Sildenafil citrate in threatened preterm labour has yet to be determined.

Sildenafil causes dose dependent hypotension i.e. single oral dose upto $200 \mathrm{mg}$ produced no significant changes in Cardiac Index as depicted in study done by Graham Jackson et al. ${ }^{6}$ Maximum observed plasma concentrations of Sildenafil increased proportionally with dose, with an evidence of orthostatic effect. More ever study done by Ali et al had shown considerable side effects of sildenafil citrate on mother and fetus with oral administration therefore in current study, sildenafil citrate was given vaginally ( $25 \mathrm{mg}$ at 8 hourly for 72 hours) with mean dose of $205.6 \pm 46.87 \mathrm{mg}$ because of its efficacy and safety, with fewer adverse systemic events, and to limit the concern regarding the feto-maternal unit. ${ }^{7}$ Similar trial was also conducted by El-Far et al, Maher et al and Khan et al in which vaginal route for sildenafil citrate was preferred. ${ }^{2,8,9}$

Total mean dose of nifedipine in both the regimens were $134.5 \pm 16.94$ and $131.0 \pm 23.07 \mathrm{mg}$. None of the participant required repeated dose of any regimen. Maher et al in their trial had shown superior tocolytic effect of nifedipine and sildenafil citrate combination to that of nifedipine alone. ${ }^{2}$ In current study we have also observed superior efficacy of nifedipine and sildenafil citrate combination as compared to nifedipine alone in terms of inhibiting preterm labour and improving perinatal outcomes.

Undelivered women were given $200 \mu \mathrm{g}$ of micronized progesterone vaginally as maintenance therapy till 34 weeks. Similar to our study, Tejada et al and Palacio et al had also used progesterone after acute tocolysis. ${ }^{10,11}$

Efficacy of any tocolytic therapy can be tested by latency i.e. time in days from randomization till delivery. In present study, we observed higher mean latency in sildenafil and nifedipine combination regimen compared to nifedipine alone regimen $(28.23 \pm 18.3$ versus
$12.98 \pm 13.35$ days). Chiossi and colleagues hypothesized that sildenafil citrate may potentiate the tocolytic effect of nifedipine in their in vitro model of myometrial biopsies. ${ }^{12}$ Maher et al also referred higher latency in nifedipine and sildenafil citrate group. ${ }^{2}$ In contrast, Ali et al had also documented nearly same relaxing effect of both sildenafil and nifedipine on myometrium to prevent preterm birth. $^{7}$

In recent study fewer deliveries occurred during hospitalization or within 7 days after discharge hence more women remains undelivered in combination regimen. Similar outcomes were seen in study done by Maher et al. ${ }^{2}$ Study done by Ali et al and Abdelhamid et al found equal efficacy of sildenafil and nifedipine in preterm birth management. ${ }^{7,13}$ Only few studies are available in literature to compare both regimen outcomes.

Combination regimen found to improve perinatal outcomes in the form of fewer deliveries during hospitalization or within 7 days after discharge; prolonged latency; reduction in NICU admission and stay; improvement in neonatal birth weight and fewer neonatal complications of prematurity. The findings of Maher et al, Ali et al are in harmony with our study regarding perinatal outcomes. ${ }^{2,7}$

In our study, only minor side effects such as facial flushing, headache, dyspepsia were seen in both regimen because of acute tocolytics, although facial flushing, headache and dyspepsia were more in sildenafil and nifedipine regimen.

\section{CONCLUSION}

Prevention of preterm labour has the priority in health care system since preventive measures are superior to treatment protocols. An ideal tocolytic agent should be safe, well tolerated, easily administered, rapidly absorbed and should have strong relaxing effect on myometrium to prevent preterm labour. Although nifedipine is proved first line tocolytic therapy but most of the criteria of ideal tocolytic agent are also fulfilled by sildenafil citrate. Further, effects of tocolytics are intensified through synergistic effect of sildenafil with nifedipine. Our trial preferred vaginal route for administration of sildenafil citrate because of its efficacy and safety with fewer adverse systemic events. Sildenafil citrate as vaginal suppositories proved to be an interesting cost effective, novel, safe option for preventing preterm birth. Our study found combination of sildenafil citrate with nifedipine as superior and successful regimen with future potential as a tocolytic therapy. We recommends larger multicentric trials for better evaluation of benefits and adverse effects of combination regimen on fetus and mother as prophylactic agent in preterm labour.

Funding: No funding sources

Conflict of interest: None declared 
Ethical approval: The study was approved by the Institutional Ethics Committee

\section{REFERENCES}

1. Arias F, Bhide AG, Arulkumaran S, Damania K, Daftary SN, eds. Arias' Practical Guide to High-Risk Pregnancy and Delivery: A South Asian Perspective. 4th edn. Elsevier India; 2014:135-140.

2. Maher MA, Sayyed TM, El-Khadry SW. Retracted: Nifedipine alone or combined with sildenafil citrate for management of threatened preterm labour: a randomised trial. BJOG. 2019;126(6):729-35.

3. Van Geijn HP, Lenglet JE, Bolte AC. Nifedipine trials: effectiveness and safety aspects. BJOG. 2005;112:79-83.

4. Dunn L, Greer R, Flenady V, Kumar S. Sildenafil in pregnancy: a systematic review of maternal tolerance and obstetric and perinatal outcomes. Fet Diagnos Therap. 2017;41(2):81-8.

5. Villanueva-Garcia D, Mota-Rojas D, HernandezGonzalez R, Sanchez-Aparicio P, Alonso-Spilsbury $\mathrm{M}$, Trujillo-Ortega ME, et al. A systematic review of experimental and clinical studies of sildenafil citrate for intrauterine growth restriction and pre-term labour. J Obstet Gynaecol. 2007;27(3):255-9.

6. Jackson G, Benjamin N, Jackson N, Allen MJ. Effects of sildenafil citrate on human hemodynamics. Am J Cardiol. 1999;83(5):13-20.

7. Abd El-Naser Abd El-Gaber Ali, Khaled M Abdallah, Ahmed Abdelhamid. Sildenafil Citrate versus Nifedipine and Dydrogesreone in Prevention of Preterm Labor with Short Cervix J. Obstetrics Gynecology and Reproductive Sciences.

8. El-Far M, El-Motwally AE, Abou Hashem I, Bakry N. Biochemical role of intravaginal sildenafil citrate as a novel antiabortive agent in unexplained recurrent spontaneous miscarriage: first clinical study of four case reports from Egypt. Clin Chem Lab Med. 2009;47(11):1433-8.

9. Khan RN, Hamoud H, Warren A, Wong LF, Arulkumaran S. Relaxant action of sildenafil citrate (Viagra) on human myometrium of pregnancy. Am J Obstet Gynecol. 2004;191(1):315-21.

10. De Tejada BM, Karolinski A, Ocampo MC, Laterra C, Hösli I, Fernández D, et al. Prevention of preterm delivery with vaginal progesterone in women with preterm labour (4P): randomised double-blind placebo-controlled trial. BJOG. 2015;122(1):80-91.

11. Palacio M, Cobo T, Antolín E, Ramirez M, Cabrera F, Mozo de Rosales F, et al. Vaginal progesterone as maintenance treatment after an episode of preterm labour (PROMISE) study: a multicentre, doubleblind, randomised, placebo-controlled trial. BJOG. 2016;123(12):1990-9.

12. Chiossi G, Costantine MM, Betancourt A, Hankins GD, Longo M, Saade GR, et al. Does sildenafil citrate affect myometrial contractile response to nifedipine in vitro? Am J Obstet Gynecol. 2010;203(3):252-e1.

13. Abdelhamid A. Comparative study of sildenafil citrate versus dydrogesterone in prevention of preterm labour in pregnant women with short cervix. Al-Azhar Assiut Med J. 2015;13(3):1.

Cite this article as: Karya U, Rani A, Srivastava A Tocolytic effect of combined sildenafil citrate and nifedepine versus nifedipine alone for management of preterm labour at a tertiary centre. Int J Reprod Contracept Obstet Gynecol 2021;10:1596-601. 